\title{
Diabetes Mellituslu Hastalarda Koroner Sinüs Gerginliğinin Değerlendirilmesi
}

\section{Evaluation of Coronary Sinus Strain in Patients with Diabetes Mellitus}

\author{
İbrahim Halil Ozdemir ${ }^{1 *}$, Uğur Kemal Tezcan ${ }^{2}$ \\ ${ }^{1}$ Manisa Şehir Hastanesi, Kardiyoloji Bölümü, Manisa, Türkiye \\ ${ }^{2}$ Manisa Celal Bayar Üniversitesi Tıp Fakültesi , Kardiyoloji Anabilim Dalı, Manisa, Türkiye \\ e-mail: dr.ibrahimhalilozdemir@gmail.com,uktezcan@hotmail.com \\ ORCID: 0000-0003-3953-4387 \\ ORCID: 0000-0002-2445-8089 \\ *Sorumlu yazar/ Corresponding Author: İbrahim Halil Özdemir \\ Gönderim Tarihi / Received: 08.10.2020 \\ Kabul Tarihi / Accepted: 09.12.2020 \\ DOI: $10.34087 /$ cbusbed. 807737 \\ $\ddot{\mathbf{O} z}$
}

Giriş ve Amaç: Diabetes mellitus (DM) önemli bir halk sağlığı sorunu olmaya devam etmektedir. Eşlik eden küçük ve büyük damar hastalıkları, yüksek morbidite ve mortalite ile ilişkili organ disfonksiyonuna yol açar. Bu çalışma, koroner sinüs gerilmesinin (stain) değerlendirilmesi ile diyabetin kardiyak venöz sistem üzerindeki etkisini ele almıştır.

Gereç ve Yöntemler: Kalp yetersizliği ve kalp kapak patolojisi dışlanan 49 DM'li ve 53 DM'siz hasta çalışmaya dahil edildi. Her iki grupta da koroner sinüs gerilmesi (CSS) ekokardiyografi ile değerlendirildi. Ek olarak, DM'nin arteriyel sistem üzerindeki etkilerini değerlendirmek için her iki grupta aort gerilmesi (AS) değerlendirildi.

Bulgular: CSS hasta grubunda 113,16 $\pm 17,89$, kontrol grubunda $165,12 \pm 19,30$ idi. Hastaların ve kontrollerin ortalama

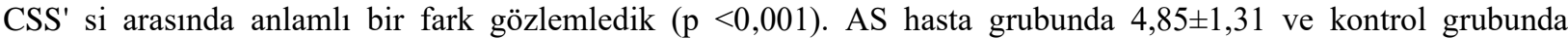
$10,60 \pm 2,64$ idi. AS, DM ve kontrol grupları arasında istatistiksel olarak farklıydı ( $p<0,001)$.

Sonuç: Bu çalışmada, DM' nin arteriyel sistem üzerindeki etkileri AS tarafından değerlendirilmiş ve sonuçlar önceki araştırma ve yayınlarla uyumlu görünmektedir. Koroner sinüsün ekokardiyografik değerlendirmesi, DM hastalarında kardiyak venöz sistemde bir değişiklik olduğunu düşündürmektedir.

Anahtar kelimeler: Diyabetes mellitus, Ekokardiyografi, Gerginlik, Koroner sinüs.

\section{Abstract}

Objective Diabetes mellitus (DM) remains a major public health problem. The accompanying small and large vessel diseases lead to organ system dysfunction associated with a high morbidity and mortality This study adressed the effect of diabetes on cardiac venous system by assessment of the coronary sinus strain..

Material and Methods: : 49 patients with and 53 without DM were included in the study, whose heart failure and heart valve pathology were excluded. Coronary sinüs strain (CSS) was evaluated with echocardiography in both groups. In addition, the aortic strain (AS) was assessed in both groups to evaluate the effects of DM on the arterial system.

Results: CSS was $113,16 \pm 17,89$ in the patient group and 165,12 $\pm 19,30$ in the control group. We observed a significant difference between the mean CSS of the patients and the controls ( $p<0,001$ ). AS was $4,85 \pm 1,31$ in the patient group and 10,60 $\pm 2,64$ in the control group. AS was statistically different between DM and control groups $(p<0,001)$.

Conclusion: In the present study, the effects of DM on arterial system were evaluated by AS and results appear consistent with prior research and publications. The echocardiographic evaluation of the coronary sinus suggest an alteration of the cardiac venous system in DM patients.

Keywords: 2D Echocardiography, Coronary sinus, Diabetes mellitus, Strain.

\begin{tabular}{ll}
\hline 1.Introduction & effect, or both. It shows its harmful effects with \\
Diabetes mellitus (DM) is a chronic metabolic disease & hyperglycemia. Over time, micro and / or macrovascular \\
accompanied by insulin deficiency, decreased insulin & complications occur due to hyperglycemia [1]. Chronic
\end{tabular}


complications lead to long-term organ dysfunction related to small and large vessel vascular diseases. Complications related to diabetes mellitus often depend on arterial system pathologies (such as coronary arteries disease, peripheral arteries disease). However, it should be remembered that it also makes pathology in the venous system. For example, in diabetic retinopathy, dilatation was observed in the venous vessels, while no pathology was detected in the arterial system [2]. Similarly, in a study investigating risk factors for venous thromboembolism, DM was found to be an important risk factor [3]. Diabetes mellitus is an important cardiovascular risk factor. We think that diabetes mellitus, which makes pathology at many different points in the heart, also has pathology in the coronary venous system, which has increased in importance in recent years.

Coronary venous system is paramount in electrophysiological procedures such as arrhythmia ablation, placement of cardiac devices as biventricular pacing [4-6]. The coronary sinüs (CS) is the main cardiac vein of the heart. The CS length varies from 3 to 5,5 centimeters and extends transversely in the left atrioventricular Groove [7]. CS collects venous blood in the heart muscle during ventricular systole. During atrial systole, venous blood is poured into the right atrium via the coronary sinus.

We planned our study to examine the effects of diabetes mellitus on the cardiac system. We compared the echocardiographic findings of diabetic patients with the healthy control group. There are studies on arterial system and diastolic parameters in the literature. However, there is not enough research on the coronary venous system. In our study, we aimed to evaluate the effect of DM on the main cardiac vein coronary sinus of the heart.

\section{Materials and Methods}

\subsection{Study design}

The research protocol complies with the Declaration of Helsinki and was approved by Celal Bayar University Medicine Faculty Non-Interventional Clinical Trials Ethics Committee (decision no. 2047848673/11.02.2015). Every patient/legal representative signed a written informed consent, accepting the procession of personal data for scientific purposes at the moment of hospital admission.

The study and control groups were selected among the patients referred to the cardiology outpatient clinic between 2014 and 2016. The study population consists of 49 patients and 53 control groups. All participants were given full information about the study details and informed consent was obtained. The patient group was selected from patients diagnosed according to the American Diabetes Association (ADA) criteria and receiving either an oral antidiabetic or insulin. The control group was selected from healthy individuals without diabetes. Gender, age, body mass index, body surface area, smoking, systolic and diastolic blood pressures of the patient and control groups included in the study were recorded. Oral antidiabetic and insulin use was recorded in diabetic patients. Fasting blood glucose, urea, creatinine, uric acid, aspartate transaminase, alanine transaminase, $\mathrm{HbA} 1 \mathrm{C}$, calcium, potassium and whole blood counts were performed in patients and control group included in the study. Vasculitis and degenerative diseases were excluded by looking at rheumatoid factor, anti nuclear antibody, anti cytoplasmic antibody (in the study and control group). Patients with high creatinine were excluded from the study (in the study and control group). Patients who used antihypertensive therapy and who had elevated blood pressure measurement were excluded from the study (in the study and control group). Patients with severe valvular pathology and heart failure (left ventricular regional wall motion defect) were excluded from the study and control groups. Patients with rhythm other than normal sinus rhythm and ECG findings suggesting myocardial ischemia such as $\mathrm{T}$ wave negativity or ST segment depression were excluded from the study. In addition, patients with left ventricular hypertrophy (LVMI)> $125 \mathrm{~g} / \mathrm{m} 2$ for men and $>110 \mathrm{~g} /$ $\mathrm{m} 2$ for women were not included in the study.

\subsection{Ecocardiographic Analysis}

All echocardiographic examinations were performed by the same investigator using General Electric Vivid 3 echocardiography (GE Vingmed Ultrasound AS, Horten Norway). Patients were evaluated in the left lateral decubitus position using standard image windows (parasternal long axis, parasternal short axis, apical imaging) as depicted in the literature. In parasternal long axis imaging, ascending aorta systolic and diastolic measurements were made $3 \mathrm{~cm}$ distal to the aortic valve (Figure-1A). Ventricular septum thickness, left ventricular posterior wall thickness, left ventricular systolic and diastolic diameters were measured in the systolic and diastolic stages without visualizing the parasternal long axis (Figure-1B). These measurements were done with M-mode. Left ventricular ejection fraction (EF) was evaluated by the modified Simpson Method. Fractional shortening (FS) was evaluated using M-mode imaging. Diastolic functions were calculated by mitral valve pulse doppler measurements. Early diastolic peak flow rate $(\mathrm{E})$, late diastolic peak flow rate $(\mathrm{A}), \mathrm{E} /$ $A$ ratio and deceleration time (DT) were measured (Figure-2A-B). Apical four-chamber imaging was modified to image the coronary sinus. CS diameter was evaluated using M-Mode. The maximum CS diameter was measured at the end of the ventricular systole and the minimum diameter during atrial contraction. Measurements were made from the mid region of CS (Figure-3).

\subsection{Statistical analysis}

SPSS package program (Statistical Package for the Social Sciences, Version 15.0, SPSS Inc., Chicago, Illinois, USA) was used for statistical analysis of all data. The Chi-square test was performed for the analysis of the categorical variables and the Student's T and MannWhitney U tests were performed for the analysis of the continuous variables. ANOVA was used in triple and and 


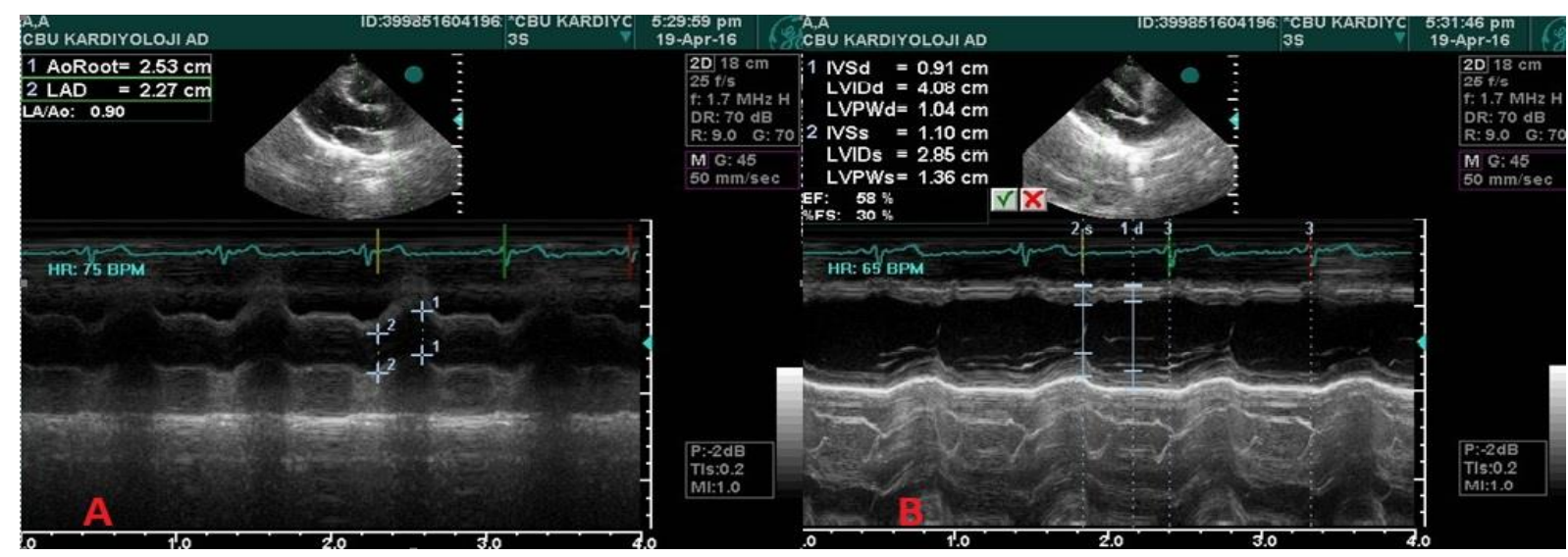

Figure 1. A- Aortic Strain Measurement, B- Left Ventricular Mass Determination

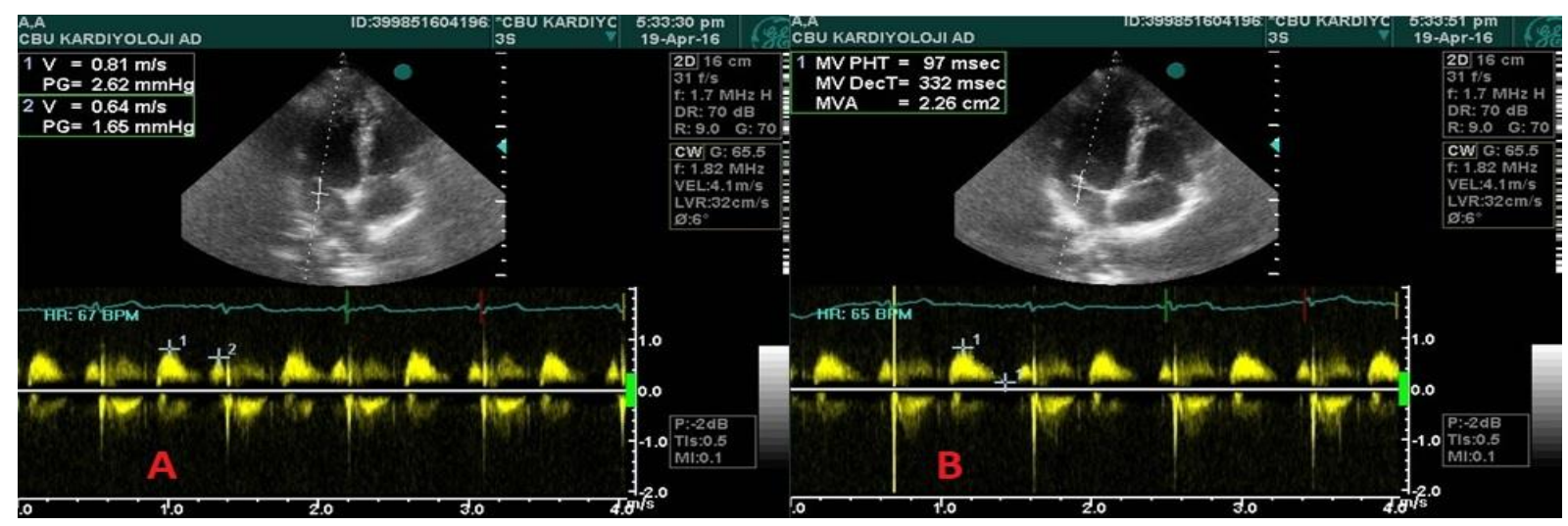

Figure 2. A- The mitral valve tips and early diastolic peak flow velocity (E), late diastolic peak flow velocity (A), BMitrat Valve Deceleration Time (DT)

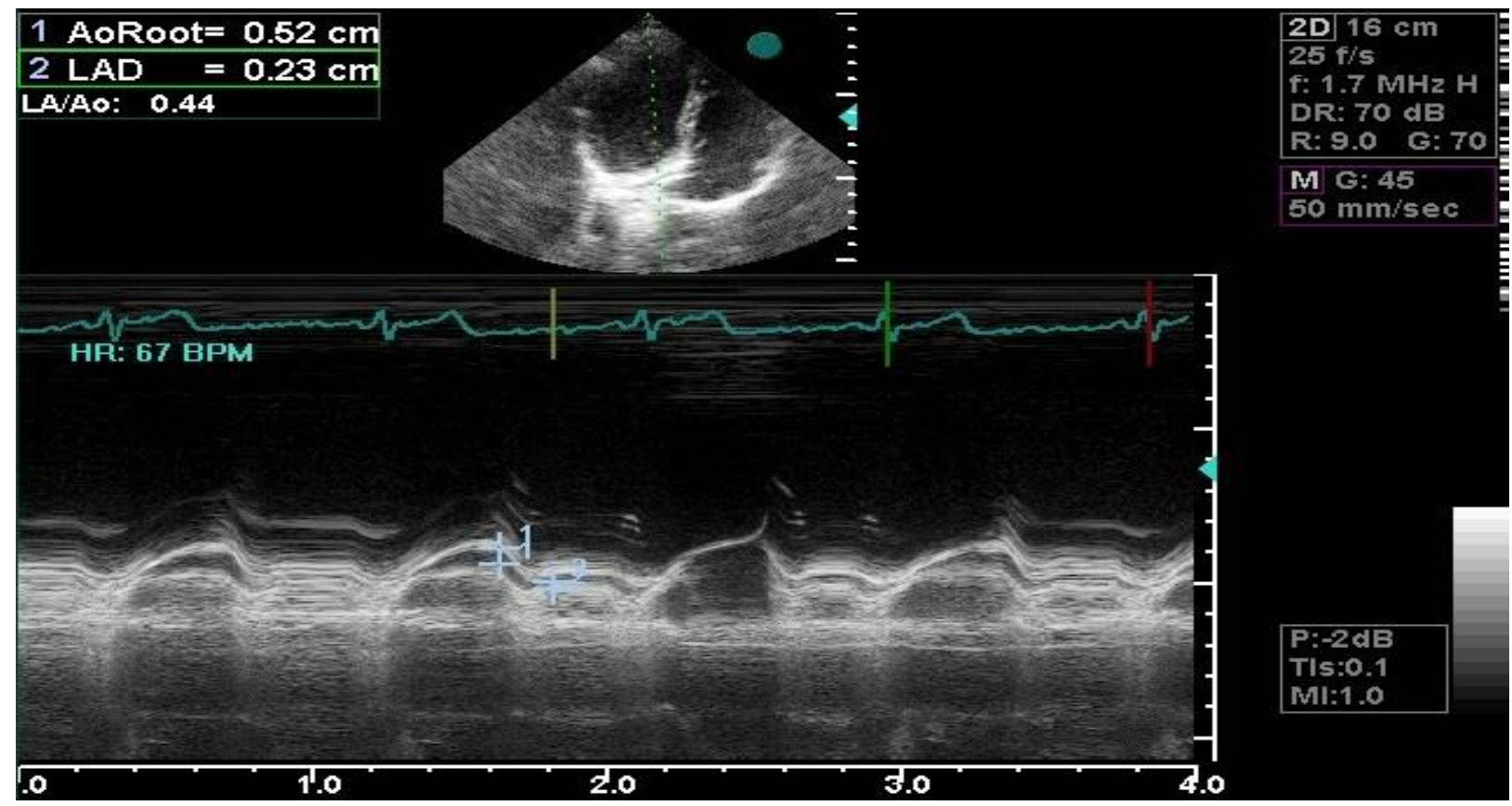

Figure 3. Coronary Sinus Strain Measurement

Aortic strain, LVMI and coronary sinus strain measure formulas:

Aortic Strain (AS) $=100 \times($ AoSD - AODD) $/$ AoDD

$\mathrm{LVM}=0.80 \times\left\{1.04 \times\left[(\text { Septal thickness }+\mathrm{LV} \text { inner diameter }+ \text { Back wall thickness })^{3}-(\mathrm{LV} \text { inner diameter })^{3}\right]\right\}+$ 0.6g. LVMI: LVM / BSA

Coronary Sinus Strain $(\mathrm{CSS})=($ Maximum CS Diameter - Minimum CS Diameter $) /$ Minimum CS Diameter x 100 
multiple comparisons. A p-value $<0,05$ was considered statistically significant.

\section{Results and Discussion}

\subsection{Results}

There was no statistical difference between sex distribution (p:0,843), age (years) (p:0,055), body mass index $\left(\mathrm{kg} / \mathrm{m}^{2}\right) \quad(\mathrm{p}: 0,114)$, body surface area $\left(\mathrm{m}^{2}\right)$ (p:0,089), smoking (p:0,120), and blood pressure measurement $(\mathrm{mmHg})$ (systolic: $\mathrm{p}: 0,332)$, (diastolic: $\mathrm{p}: 0,245$ ) between patient and control groups (Table-1). There was no statistical difference in urea $(\mathrm{mg} / \mathrm{dl})$ (p:0,118), serum creatinine $(\mathrm{mg} / \mathrm{dl})(\mathrm{p}: 0,095)$, serum potassium (mmol/l) (p:0,598), serum calcium $(\mathrm{mg} / \mathrm{dl})$ (p:0,364), uric acid (mg/dl) (p:0,139), albümin (g/dl) (p:0,228), aspartate transaminase $(\mathrm{u} / \mathrm{l})(\mathrm{p}: 0,334)$, alanine transaminase $(\mathrm{u} / \mathrm{l}) \quad(\mathrm{p}: 0,398)$, hemoglobin $(\mathrm{g} / \mathrm{dl})$ (p:0,324), hematocrit (\%) (p:0,426) and Red Cell Distribution Width (RDW) (\%) (p:0,417) measurements between patient and control groups (Table1).Statistically significant highness was observed in fasting blood glucose $(\mathrm{mg} / \mathrm{dl})$ and $\mathrm{HbA1c}(\%)$ in the diabetic group $(\mathrm{p}<0,001)$. Of the diabetic patients, 14 $(28,6 \%)$ had oral antidiabetic, $31(63,3 \%)$ had insulin only, and $4(8,1 \%)$ had oral antidiabetic + insulin history. There was no history of drug use in the control group (Table 1).

Table 1. Demographic Datas, Laboratory Parameters and Medications

\begin{tabular}{|c|c|c|c|}
\hline & $\begin{array}{c}\text { Patients with } \\
\text { Diabetes Mellitus } \\
(n=49)\end{array}$ & $\begin{array}{l}\text { Patients without } \\
\text { Diabetes Mellitus } \\
\quad(n=53)\end{array}$ & $p$ value \\
\hline Age, years & $58,53 \pm 6,82$ & $56,06 \pm 5,81$ & 0,055 \\
\hline Female sex, n (\%) & $24(49)$ & $27(50,9)$ & 0,843 \\
\hline Smoking, n (\%) & $14(28,6)$ & $23(43,4)$ & 0,120 \\
\hline Body surface area $\left(\mathbf{m}^{2}\right)$ & $1,87 \pm 0,13$ & $1,83 \pm 0,14$ & 0,089 \\
\hline Body mass index, $\mathrm{kg} / \mathrm{m}^{2}$ & $28,84 \pm 5,10$ & $27,17 \pm 4,69$ & 0,114 \\
\hline Systolic blood pressure, $\mathrm{mmHg}$ & $132,88 \pm 18,27$ & $127,75 \pm 22,65$ & 0,332 \\
\hline Diastolic blood pressure, $\mathrm{mmHg}$ & $79,55 \pm 8,43$ & $77,70 \pm 7,76$ & 0,245 \\
\hline \multicolumn{4}{|l|}{ Laboratory parameters } \\
\hline Fasting blood glucose , mg/dl & $187,10 \pm 36,55$ & $96,23 \pm 12,39$ & $<0,001$ \\
\hline Urea, mg/dl & $29,04 \pm 13,41$ & $27,06 \pm 15,71$ & 0,118 \\
\hline Serum creatinine, mg/dl & $0,73 \pm 0,13$ & $0,69 \pm 0,19$ & 0,095 \\
\hline Serum potassium, $\mathrm{mmol} / \mathrm{l}$ & $4,1 \pm 0,8$ & $4,4 \pm 0,5$ & 0,598 \\
\hline Serum calcium, mg/dl & $9,1 \pm 1,2$ & $9,5 \pm 0,9$ & 0,364 \\
\hline Uric acid, mg/dl & $5,2 \pm 1,3$ & $5,8 \pm 0,8$ & 0,139 \\
\hline Albumin, g/dl & $4,3 \pm 0,9$ & $4,0 \pm 1,3$ & 0,228 \\
\hline Aspartate transaminase, $u / l$ & $29 \pm 16$ & $32 \pm 13$ & 0,334 \\
\hline Alanine transaminase, $u / l$ & $17 \pm 17$ & $21 \pm 14$ & 0,398 \\
\hline HbA1c\% & $9,2 \pm 0,8$ & $6,1 \pm 0,2$ & $<0,001$ \\
\hline Haemoglobin, g/dl & $13,9 \pm 1,25$ & $13,7 \pm 1,25$ & 0,324 \\
\hline Hematocrit \% & $44 \pm 12$ & $47 \pm 9$ & 0,426 \\
\hline RDW \% & $14 \pm 0,6$ & $13,8 \pm 1,4$ & 0,417 \\
\hline \multicolumn{4}{|l|}{ Medications } \\
\hline Oral antidiabetic, $n(\%)$ & $14(28,6)$ & 0 & $<0,001$ \\
\hline Insulin, n(\%) & $31(63,3)$ & 0 & $<0,001$ \\
\hline Oral antidiabetic+Insulin, n(\%) & $4(8,1)$ & 0 & $<0,001$ \\
\hline
\end{tabular}

\footnotetext{
\pm SD: Standard Deviation
}

Abbreviations: BMI: Body mass index, BSA: Body surface area, RDW: Red cell distribution width

There was no statistical difference between the patient and control groups in the measurements of interventricular septum diastolic diameter $(\mathrm{cm})$ (p:0,069), interventricular septum systolic diameter $(\mathrm{cm})$ (p:0,198), posterior wall diastolic diameter $(\mathrm{cm})$ (p:0,254), posterior wall systolic diameter $(\mathrm{cm})$ (p:0,090), left ventricular diastolic diameter $(\mathrm{cm})$ (p:0,176), and left ventricular systolic diameter $(\mathrm{cm})$ (p:0,112). There was no statistical difference between the patient and control groups in fractional shortening (FS) (\%) (calculated with M-mode) (p:0,060) and ejection fraction (EF) (\%) (calculated with the simpson method) (p:0,134). The left ventricular mass index (LVMI) $\left(\mathrm{g} / \mathrm{m}^{2}\right)$ calculated by left ventricular diameters, was not statistically different between the patient and control groups (p:0,055) (Table 2). 
Table-2 Left Ventricular Structure and Function

\begin{tabular}{|l|c|c|c|}
\hline & $\begin{array}{c}\text { Patients with } \\
\text { Diabetes Mellitus } \\
(\mathbf{n = 4 9 )}\end{array}$ & $\begin{array}{c}\text { Patients without } \\
\text { Diabetes Mellitus } \\
(\mathbf{n = 5 3 )}\end{array}$ & $\boldsymbol{p}$ value \\
\hline IVSDD (cm) & $1,23 \pm 0,13$ & $1,10 \pm 0,16$ & 0,069 \\
\hline IVSSD (cm) & $1,51 \pm 0,19$ & $1,37 \pm 0,22$ & 0,198 \\
\hline PWDD (cm) & $1,33 \pm 0,15$ & $1,23 \pm 0,19$ & 0,254 \\
\hline PWSD (cm) & $1,66 \pm 0,26$ & $1,58 \pm 0,31$ & 0,090 \\
\hline LVDD (cm) & $4,90 \pm 1,23$ & $4,65 \pm 1,46$ & 0,176 \\
\hline LVSD (cm) & $3,12 \pm 0,96$ & $2,96 \pm 1,12$ & 0,060 \\
\hline FS \% & $37,16 \pm 3,25$ & $35,87 \pm 3,59$ & 0,134 \\
\hline EF\% & $66,73 \pm 3,72$ & $65,47 \pm 4,62$ & 0,055 \\
\hline LVMI (g/m $\mathbf{2})$ & $103,28 \pm 12,30$ & $99,01 \pm 9,89$ & 050 \\
\hline
\end{tabular}

\pm SD: Standard Deviation

Abbreviations: IVSDD:Interventricular septum diastolic diameter, IVSSD: Interventricular septum systolic diameter, PWDD: Posterior wall diastolic diameter, PWSD: Posterior wall systolic diameter, LVDD: Left ventricular diastolic diameter, LVSD: Left ventricular systolic diameter, FS: Fractional shortening, EF: Ejection fraction, LVMI: Left ventricular mass index

A statistically significant difference was found between the patient and control groups in the aortic diastolic diameter $(\mathrm{cm})(\mathrm{p}<0,001)$, aortic systolic diameter $(\mathrm{cm})$ $(\mathrm{p}<0,05)$ and aortic strain $(\mathrm{p}<0,001)$ (Table 3).

Table-3 Aortic Structure

\begin{tabular}{|l|c|c|c|}
\hline & $\begin{array}{c}\text { Patients with } \\
\text { Diabetes Mellitus (n=49) }\end{array}$ & $\begin{array}{c}\text { Patients without } \\
\text { Diabetes Mellitus (n=53) }\end{array}$ & $\boldsymbol{p}$ value \\
\hline AoDD (cm) & $2,96 \pm 0,34$ & $2,63 \pm 0,31$ & $<0,001$ \\
\hline AoSD (cm) & $3,10 \pm 0,37$ & $2,91 \pm 0,32$ & $<0,05$ \\
\hline AS & $4,85 \pm 1,31$ & $10,60 \pm 2,64$ & $<0,001$ \\
\hline
\end{tabular}

\pm SD: Standard Deviation

Abbreviations: AoDD: Aortic diastolic diameter, AoSD: Aortic systolic diameter, AS: Aortic strain

When the diastolic parameters of the patient and control groups were evaluated, a statistically significant difference was found between E (m/s), A (m/s) and E / A ratio $(\mathrm{p}<0,001)$. There was no statistical difference in DECT (msec) (p: 0,108) (Table 4).

Table-4 Ventricular Diastolic Parameters

\begin{tabular}{|l|c|c|c|}
\hline & $\begin{array}{c}\text { Patients with } \\
\text { Diabetes Mellitus (n=49) }\end{array}$ & $\begin{array}{c}\text { Patients without } \\
\text { Diabetes Mellitus (n=53) }\end{array}$ & $\boldsymbol{p}$ value \\
\hline Mitral E Velocity (m/s) & $0,76 \pm 0,05$ & $0,84 \pm 0,04$ & $<0,001$ \\
\hline Mitral A Velocity (m/s) & $0,87 \pm 0,07$ & $0,75 \pm 0,04$ & $<0,001$ \\
\hline Mitral E/A Ratio & $0,77 \pm 0,18$ & $1,09 \pm 0,37$ & 0,108 \\
\hline DT (msec) & $212,35 \pm 12,72$ & $207,89 \pm 14,92$ & $<01$ \\
\hline
\end{tabular}

\pm SD: Standard Deviation

Abbreviations: DT: Deceleration time

When we look at the coronary sinus values of the patient and control groups, there was a statistically significant difference in Coronary Sinus Minimum diameter $(\mathrm{CSMIN})(\mathrm{cm})(\mathrm{p}: 0,005)$ and Coronary Sinus Strain
(CSS) ( $\mathrm{p}<0,001)$. There was no statistically significant difference in Coronary Sinus Maximum diameter $(\mathrm{CSMAX})(\mathrm{cm})(\mathrm{p}: 0,229)$ (Table 5). 
Table-5 Coronar Sinus Structure

\begin{tabular}{|l|c|c|c|}
\hline & $\begin{array}{c}\text { Patients with } \\
\text { Diabetes Mellitus }(\mathbf{n = 4 9 )}\end{array}$ & $\begin{array}{c}\text { Patients without } \\
\text { Diabetes Mellitus }(\mathbf{n = 5 3})\end{array}$ & $\boldsymbol{p}$ value \\
\hline CSMIN (cm) & $0,28 \pm 0,07$ & $0,24 \pm 0,06$ & 0,005 \\
\hline CSMAX $(\mathbf{c m})$ & $0,59 \pm 0,14$ & $0,63 \pm 0,15$ & 0,229 \\
\hline CSS & $113,16 \pm 17,89$ & $165,12 \pm 19,30$ & $<0,001$ \\
\hline
\end{tabular}

Abbreviations: CSMIN: Coronary Sinus Minimum diameter, CSMAX:Coronary Sinus Maximum diameter, CSS: Coronary sinüs strain

\subsection{Discussion}

Our study evaluates the effect of diabetes mellitus on the cardiovascular system. When the literature is examined, it was observed that there is not enough study especially on the coronary venous system. In order to evaluate the coronary venous system, the main cardiac vein, coronary sinus, was studied. A new parameter, coronary sinus strain, was used to evaluate the coronary sinus. CSS was first evaluated on hypertensive patients. In this study, in which diabetes mellitus was excluded, CSS decreased in hypertensive patients [8]. In our study, there was no evidence of atherosclerotic vascular disease in our patients, while CSS decreased in patients with diabetes mellitus. This data suggested that diabetes could make a pathology in the venous system before the arterial system. The data that pushed us to this idea are the effect of diabetes on the development of retinopathy and venous thromboembolism. Diabetic retinopathy is characterized by diffuse dilatation of the retinal veins in the early stages of the disease. As time progresses, pathology is observed in the retinal arteries [2]. Diabetes increases the risk of thrombosis in deep leg veins. Diabetes increases thromboembolism risk by causing endothelial dysfunction in venous vessels [3]. This risk is independent of the pathology seen in the arterial system. Even if the arterial system is in normal condition, there is a risk of venous thromboembolism because diabetes can pathology only in the venous vessels in the early stages. CSS is a parameter that can be easily calculated by echocardiography. In diabetic patients who do not have atherosclerotic heart disease, early vascular system pathologies can be detected by calculating CSS.

Diabetes causes changes in vascular structure and function before diffuse atherosclerosis develops. It causes aortic stiffness to increase and elasticity to decrease [9]. There are many studies showing that diabetes causes a decrease in aortic strain [10-11-12]. In addition to these studies evaluating the arterial structure, we have also evaluated the coronary venous system. In our study, AS was lower in diabetic patients than in the control group. CSS data had a positive correlation with AS. In addition to AS evaluating the arterial structure, evaluating CSS can enable us to estimate the level of damage caused by hyperglycemia. There was a positive correlation between fasting blood glucose-HbA1c levels and AS and CSS. As levels increased, the decrease in AS and CSS was greater.

Diabetes not only affects the vascular structure in the early period, but also affects the work of the heart. Diastolic dysfunction is observed in the early stages.
Clinical studies consider DM as a risk factor for left ventricular diastolic dysfunction. Recent cross-sectional studies have shown an increase in diastolic dysfunction in prediabetic patients, and the severity of dysfunction correlates with the degree of impaired glucose metabolism [13]. In Gani bajraktari et al. evaluated left ventricular diastolic function using pulsed Doppler echocardiography in 114 patients with insulin-dependent $\mathrm{dm}$ and 114 healthy controls. The ratio between maximum early filling rate ( $\mathrm{E}$ wave) and maximal late (atrial) filling rate (A wave) is less than 1 (E/ A ratio <1), which is accepted as a criterion for left ventricular diastolic dysfunction. E / A ratio <1 was found in 75 patients $(65,8 \%)$ in the diabetic group and 38 patients $(33,3 \%)$ in the control group ( $\mathrm{P}<0,001)$. The multiple logistic regression model showed the strongest independent correlation of diabetes left ventricular diastolic dysfunction (ratio rate 8,92, 95\% confidence interval [CI] 4,20 to 18,52, P <0,001) [14]. In our study, a statistically significant difference was found between $\mathrm{E}, \mathrm{A}$ and $\mathrm{E} / \mathrm{A}$ ratio. There is no difference in DT due to early stage diastolic dysfunction. Its early stage in diastolic dysfunction suggests that CSS is impaired in the early period of diabetes. Annou AK et al., investigated the relationship between left ventricular (LV) functional abnormalities, microangiopathy and autonomic dysfunction in non-insulin dependent diabetes mellitus (NIDDM) [15]. 66 normotensive patients (age $51+/-4,5$ years, 35 male and 31 female) with NIDDM over 4 years without heart disease were compared to age and sex matched healthy controls. Microangiopathy was evaluated by fundus examination. They reported an inverse relationship between diabetes duration and $\mathrm{E} / \mathrm{A}$ ratio $(\mathrm{r}=-0,4, \mathrm{P}<0,005)$. The $\mathrm{E} / \mathrm{A}$ ratio $<1$ was associated with a higher prevalence of retinopathy $(20 \%$ versus $49 \%, \mathrm{P}<0,01)$. LV diastolic abnormalities are associated with other diabetic microangiopathies such as duration of diabetes and diabetic retinopathy. This study suggests that diabetes may be affected in the coronary veins during the early phase because pathology occurs in the retinal veins in the early stage of diabetic retinopathy. We observed a decrease in CSS in diabetic patients which correlated with aortic strain and diastolic dysfunction. In our study, we obtained results suggesting that the cardiac venous system was affected in the early stages of diabetes. We obtained these results with the first time applied CSS calculation in diabetic patients. We may hypothesize that echocardiographic follow-up of CSS in routine practice may provide early detection of angiopathies in diabetic patients. Larger-scale studies 
would be necessary to further appreciate the value of echocardiographic evaluation of CSS as a negative predictor in patients with diabetes.

\section{Conclusion}

Echocardiographic evaluation of CSS can provide useful additional information that predicts the severity of DM and vascular involvement in the early stages of the disease. More aggressive treatment can be applied to prevent atherosclerosis in diabetic patients with decreased CSS. Hyperglycaemia control can be achieved. Routine calculation of CSS in diabetic patients undergoing echocardiography may be considered. The findings of this study on the routine use of CSS assessment need to be confirmed in larger studies..

\section{Referanslar}

1. American Diabetes Association. Diagnosis and classification of Diabetes Mellitus, Diabetes Care, 2004, 27, 5-14.

2. Kohner, E.M \& Dollery, C.T (1975): Diabetic retinopathy, In: Keen, $\mathrm{H} \&$ Jarrett, J (eds.) Complications of Diabetes, Arnold Publisher, London, 29-32.

3. Tan L, Qi B, Yu T, Wang C. Incidence and risk factors for venous thromboembolism following surgical treatment of fractures below the hip: a meta-analysis. Int Wound J. 2016;13(6):1359-1371. doi:10.1111/iwj.12533

4. Alonso, C, Leclercq, C, d'Allonnes, F.R, et al. Six year experience of transvenous left ventricular lead implantation for permanent biventricular pacing in patients with advanced heart failure: technical aspects, Heart, 2001, 86(4), 405-410. doi:10.1136/heart.86.4.405.

5. Gerber, T.C, Kantor, B, Keelan, P.C, Hayes, D.L, Schwartz, R.S, Holmes, D.R. The Coronary Venous System: An Alternate Portal to the Myocardium for Diagnostic and Therapeutic Procedures in Invasive Cardiology, Current Interventional Cardiology Reports, 2000, 2(1), 27-37.

6. Grzybiak, M. Morphology of the CS and contemporary cardiac electrophysiology, Folia Morphol (Warsz), 1996, 55, 272-3.

7. von Lüdinghausen $\mathrm{M}$, Clinical anatomy of cardiac veins, $\mathrm{Vv}$ Cardiacae, Surgical and Radiologic Anatomy, 1987, 9(2), 159-168.

8. Akcay, S, Turker, Y, Kobat, M.A, Cetin, N, Bilge, A.R, Tezcan, U.K, Evaluation of coronary sinus strain in patients with dipper and nondipper hypertension, Blood Pressure Monitoring, 2014, 19(6), 320-326.

9. Aslan, A.N, Ayhan, H, Çiçek, Ö.F, et al, Relationship between aortic stiffness and the left ventricular function in patients with prediabetes, Internal Medicine, 2014, 53(14), 1477-1484.

10. Eren, M, Gorgulu, S, Uslu, N, Celik, S, Dagdeviren, B, Tezel, T. Relation between aortic stiffness and left ventricular diastolic function in patients with hypertension, diabetes, or both, Heart, 2004, 90(1), 37-43

11. Çiftel, M, Ertuğ, H, Parlak, M, Akçurin, G, Kardelen, F, Investigation of endothelial dysfunction and arterial stiffness in children with type 1 diabetes mellitus and the association with diastolic dysfunction, Diabetes and Vascular Disease Research, 2014, 11(1), 19-25.

12. Mahfouz Badran, H, Elnoamany, M, Impact of type 2 diabetes mellitus on aortic elastic properties in normotensive diabetes: Doppler tissue imaging study, Journal of The American Society of Echocardiography, 2006, 19(12), 1471-1481.

13. Stahrenberg, R, Edelmann, F, Mende, M, et al, Association of glucose metabolism with diastolic function along the diabetic continuum [published correction appears in Diabetologia, 2011, 54(4), 990. Schönbrunn, L [added]], Diabetologia, 2010, 53(7), 1331-1340.

14. Bajraktari, G, Qirko, S, Rexhepaj, N, et al, Non-insulin dependent diabetes as an independent predictor of asymptomatic left ventricular diastolic dysfunction, Croatia Medical Journal, 2005, 46(2), 225231.

15. Annonu, A.K, Fattah, A.A, Mokhtar, M.S, Ghareeb, S, Elhendy, A, Left ventricular systolic and diastolic functional abnormalities in asymptomatic patients with non-insulin-dependent diabetes mellitus. Journal of The American Society of Echocardiography, 2001, 14(9), 885-891. http://edergi.cbu.edu.tr/ojs/index.php/cbusbed isimli yazarın CBU-SBED başlıklı eseri bu Creative Commons Alıntı-Gayriticari4.0 Uluslararası Lisansı ile lisanslanmıştır

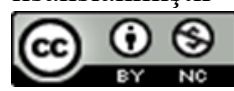

